JIIP: Jurnal Ilmiah IImu Pemerintahan

Vol. 6, No. 1, Tahun 2021

DOI: 10.14710/jiip.v6i1.10372

\title{
Infodemi Covid-19 dalam Perspektif Open Government: Sebuah Tinjauan Literatur
}

\author{
Alexander Arie Sanata Dharma ${ }^{1}$ dan Azhar Kasim ${ }^{2}$ \\ 1,2 Program Magister Ilmu Administrasi, Universitas Indonesia
}

Dikirimkan: 15 Januari 2021 Direvisi: 15 Februari $2021 \quad$ Diterbitkan: 25 Maret 2021

\begin{abstract}
INTISARI
Minimnya transparansi pada awal wabah Covid-19 menciptakan misinformasi di ruang publik. Terbentuk infodemi berupa kelimpahan informasi yang membuat masyarakat kesulitan menentukan sumber yang sahih. Penggunaan media sosial membentuk peran signifikan dalam mempengaruhi perilaku publik selama pandemi Covid-19. Pemerintah juga memberdayakan media sosial sebagai strategi komunikasi publik. Diperlukan informasi yang tepat untuk mengenali posisi media sosial pemerintah dalam infodemi Covid-19. Penelitian ini bertujuan untuk memperoleh konteks menyeluruh dari perspektif open government yaitu transparansi, partisipasi, dan kolaborasi sehingga posisi media sosial pemerintah dan infodemi Covid-19 dapat diidentifikasi sehingga mendukung strategi pemanfaatan yang lebih optimal dalam penanganan pandemi. Penelitian ini menggunakan pendekatan kualitatif dan mengumpulkan berbagai praktik pemanfaatan media sosial pemerintah secara umum dan pada konteks Covid19 di berbagai negara sebagai bahan kajian literatur. Hasil dari studi literatur memperlihatkan bahwa transparansi berkaitan dengan pemanfaatan media sosial pemerintah secara optimal, partisipasi memiliki relevansi dengan sentimen publik mengingat partisipasi memiliki kontribusi pada berkembangnya infodemi, sedangkan ruang lingkup kolaborasi adalah medium interaksi level akar rumput guna mendorong perubahan ke arah yang lebih baik. Pemerintah direkomendasikan untuk menayangkan konten secara cepat dan tepat pada platform dengan keberterimaan tinggi, memanfaatkan artificial intelligence, memoderasi komentar buruk (toxic), serta mendorong partisipasi ke arah kolaborasi antara berbagai pihak.
\end{abstract}

KATA KUNCI

infodemi; Covid-19; media sosial; open government

\section{Pendahuluan}

Sejak akhir Desember 2019, di Wuhan, Republik Rakyat Tiongkok, muncul wabah yang disebabkan oleh salah satu jenis betacoronavirus. Wabah ini menyebar dengan cepat dari 1 kota ke seluruh negara-dan kemudian dunia-hanya dalam waktu 30 hari (Wu \& McGoogan, 2020). Virus penyebab wabah memiliki kemiripan dengan Severe Acute Respiratory Syndromme

Korespodensi:

Program Magister Ilmu Administrasi Universitas Indonesia, Gedung Mochtar Jalan Pegangsaan Timur Nomor 16 Jakarta Pusat 10320.

Email: alexander.arie@ui.ac.id 
Coronavirus (SARS-CoV), hanya saja terdapat sejumlah perubahan asam amino sehingga kemudian diberi identitas sebagai SARS-CoV-2 (Sohrabi et al., 2020).

Penyakit yang disebabkan oleh SARS-CoV-2 kemudian disebut sebagai Coronavirus Disease 2019 atau Covid-19 dan segera menjadi perhatian dunia terutama sejak ditetapkan sebagai pandemi. Penyebab utamanya adalah angka kematian yang cukup tinggi. Angka case fatality rate (CFR) pada periode awal dilaporkan mencapai 2,3\%. Angka tersebut melonjak drastis menjadi $8 \%$ pada pasien berusia $70-79$ tahun dan $14,8 \%$ pada pasien dengan usia lebih dari 80 tahun. Dalam kondisi meningkatnya kasus penyakit tidak menular di dunia, bahaya dari Covid-19 semakin kontekstual karena CFR pada pasien dengan penyakit tidak menular-atau dikenal dengan komorbid-cukup tinggi yakni hipertensi (6\%), penyakit pernapasan kronis $(6,3 \%)$, diabetes (7,3\%), dan penyakit kardiovaskuler (10,5\%). Mengingat pengobatan spesifik maupun terapi pencegahan seperti obat antiviral tertarget maupun vaksin belum tersedia pada periode awal wabah, maka fokus penanganannya adalah pendekatan kesehatan masyarakat seperti isolasi, karnatina, serta pembatasan sosial maupun komunitas (Wu \& McGoogan, 2020).

Minimnya transparansi pada awal identifikasi Covid-19 menciptakan misinformasi publik sehingga menciptakan ruang bagi munculnya rumor dan spekulasi di ruang publik (Sohrabi et al., 2020). Fenomena misinformasi pada penanganan wabah penyakit yang bahkan dapat mempercepat penyebaran suatu epidemi dengan mempengaruhi dan memfragmentasi respon sosial oleh Cinelli et al. (2020) disebut sebagai infodemi. Adapun Islam et al. (2020) menyebut infodemi berhubungan dengan kelimpahan informasi-baik akurat maupun tidak-yang membuat masyarakat kesulitan untuk menemukan sumber yang terpercaya maupun panduan yang sahih ketika dibutuhkan.

Infodemi digunakan untuk mengkategorisasi rumor, stigma, maupun teori konspirasi selama terjadinya kegawatdaruratan kesehatan masyarakat. Pada wabah SARS 2002-2003, ketakutan berkembang dan menciptakan stigma pada orang Asia sehingga berdampak pada tertundanya upaya medis yang berkontribusi memperluas epidemi melalui transmisi komunitas. Pada wabah Ebola di Republik Demokratik Kongo tahun 2019, misinformasi menyebabkan kekerasan, kekacauan sosial, dan bahkan serangan yang menargetkan petugas kesehatan. Di Italia pada bulan Maret 2020, sebuah kantor berita mempublikasikan berita perihal lockdown di Italia Utara sebelum pengumuman resmi pemerintah. Hal itu mengakibatkan orang-orang bergegas meninggalkan Italia Utara menuju bagian selatan yang di kemudian hari diketahui berkontribusi pada peningkatan kasus Covid-19 di seluruh Italia (Cinelli et al., 2020; Islam et al., 2020; Sohrabi et al., 2020).

Zhang, Pian, Ma, Ni, \& Liu (2021) dalam studinya di Tiongkok menyebut bahwa sumber infodemi Covid-19 adalah platform chat seperti WeChat $(40,1 \%)$, platform berbagi video seperti Tiktok (23,4\%), dan platform berbagi berita seperti Sina News (22,1\%). Hasil studi tersebut sejalan dengan simulasi penyebaran informasi di media sosial menggunakan model epidemi yang dilakukan oleh Cinelli dalam sebuah peneltian (Cinelli et al., 2020). Menggunakan model 
pengukuran penyebaran virus, diperoleh nilai reproduksi yang mengarah pada terjadinya infodemi.

Data Digital 2020 menyebut bahwa total populasi di dunia pada tahun 2020 mencapai 7,75 miliar jiwa dan sebanyak 3,8 miliar (49\%) diantaranya merupakan pengguna aktif media sosial. Angka itu bertumbuh 9,2\% dibandingkan tahun sebelumnya. Rata-rata global menyebut bahwa rata-rata waktu dalam sehari yang digunakan untuk menggunakan media sosial mencapai 2 jam 24 menit. Adapun platform yang paling populer adalah Facebook, YouTube, WhatsApp, WeChat, Instagram, Tiktok, QQ, Qzone, Sina Weibo, dan Reddit (Kemp, 2020).

Media sosial memainkan peran signifikan dalam mempengaruhi publik selama pandemi Covid-19 sebab publik sendiri cenderung mengutamakan informasi dari media sosial (Ahmad \& Murad, 2020). Bridgman et al. (2020) mengidentifikasi bahwa terdapat hubungan yang kuat antara paparan media sosial dan mispersepsi tentang Covid-19 dan media sosial juga berhubungan dengan ketidakpatuhan masyarakat karena meningkatnya mispersepsi tentang Covid-19. Pada saat yang sama, pendekatan kesehatan masyarakat sebagai strategi untuk mengatasi pandemi membutuhkan kepatuhan masyarakat itu sendiri (Wu \& McGoogan, 2020).

Ketidakmampuan publik untuk memilih informasi dapat menciptakan rumor dan kepanikan yang menciptakan efek jangka panjang, terutama pada pertambahan kasus Covid-19. Mengingat misinformasi pada Covid-19 merupakan perkara yang menyangkut hidup dan mati, maka intervensi yang memadai dan strategi komunikasi yang tepat menjadi kebutuhan yang sangat krusial (Ahmad \& Murad, 2020; Pennycook, McPhetres, Zhang, Lu, \& Rand, 2020).

Salah satu alasan misinformasi di media sosial terjadi adalah kecenderungan sejumlah orang untuk memperlakukan seluruh informasi di media sosial setara dengan konten seperti video hewan maupun foto bayi yang tidak membutuhkan pertimbangan akurasi, sehingga kemudian berita-berita yang ditemukan di media sosial dibagikan dengan mudah (Pennycook et al., 2020).

Menghadapi kelimpahan informasi tersebut, pemerintah dituntut untuk mampu menyediakan informasi yang cepat dan handal kepada masyarakat guna melawan infodemi yang terjadi. Pada kenyataannya, dalam kebijakan untuk menghentikan penyebaran Covid-19, baik pemerintah maupun organisasi kesehatan belum cukup berhasil memberikan informasi yang handal untuk merespon perkembangan kebutuhan informasi publik (Lovari, D’Ambrosi, \& Bowen, 2020). Di sisi lain, media sosial menyediakan pemerintah suatu peluang untuk berkomunikasi langsung dengan masyarakat. Pada masa pandemi, menyebarkan pesan ke sebanyak mungkin masyarakat sangat penting untuk mengurangi penyebaran wabah (Teichmann et al., 2020). Hal itu terkait dengan peningkatan aktivitas individu untuk membagikan pemikiran, sudut pandang, sikap, dan perasaan di media sosial pada periode Covid-19 (Shoaei \& Dastani, 2020).

Pemanfaatan media sosial dalam pemerintahan telah menjadi salah satu tren utama dari praktik e-government. Media sosial memiliki peran penting pada area utama e-government yaitu 
aliran dan ketersediaan informasi dari pemerintah, penggunaan teknologi informasi untuk menciptakan dan menyediakan layanan pemerintahan yang inovatif, dampak dari teknologi informasi pada hubungan pemerintah dan masyarakat, serta peningkatan pentingnya kebijakan dan teknologi informasi pada praktik demokrasi(Criado, Sandoval-Almazan, \& Gil-Garcia, 2013). Pemanfaatan media sosial dalam kaitannya dengan pemerintahan semakin diakui setelah revolusi di Mesir yang memanfaatkan media sosial seperti Facebook, Twitter, dan YouTube secara masif (Abdelsalam, Reddick, Gamal, \& Al-shaar, 2013).

Oleh Mergel (2013), pemanfaatan media sosial untuk meningkatkan partisipasi, transparansi, dan kolaborasi antar agen pada sektor publik disebut sebagai Government 2.0. Platform media sosial menjadi perangkat utama yang memungkinkan adanya pertukaran informasi dua arah, baik di dalam institusi pemerintahan maupun melalui interaksi dengan masyarakat. Ditambahkan Bonsón, Royo, \& Ratkai (2017) bahwa interaksi merupakan elemen penting karena media sosial menciptakan kelimpahan data maupun informasi yang berpotensi menimbulkan pertanyaan mengenai akurasi, kualitas, maupun pemanfaatan data dan informasi tersebut. Salah satu parameter yang dapat mengukur interaksi tersebut adalah citizens engagement berupa pengolahan data dari berbagai aktivitas yang dilakukan oleh masyarakat di media sosial pemerintah (Bonsón \& Bednárová, 2018; Bonsón, Perea, \& Bednárová, 2019; Bonsón et al., 2017).

Terminologi citizens engagement tersebut cenderung melengkapi definisi yang dikembangkan dalam paradigma New Public Service. Denhardt \& Denhardt (2015) mendefinisikan citizens engagement sebagai kemampuan masyarakat untuk terlibat pada suatu problematika yang dianggap penting oleh masyarakat itu sendiri. Lebih lanjut, citizens engagement tersebut dapat dibangun pada batasan normatif dalam kerangka demokrasi, ataupun dimanfaatkan dalam implementasi kebijakan publik. Chen et al. (2020) menyebut bahwa citizens engagement cenderung meningkat saat terjadi dialog pada platform media sosial. Citizens engagement kemudian berperan penting untuk mengukur penerimaan masyarakat pada pesan yang disampaikan oleh pemerintah mengingat pentingnya perubahan perilaku masyarakat dalam upaya penanggulangan Covid-19 melalui pendekatan kesehatan masyarakat.

Penelitian tentang posisi media sosial pemerintah dalam infodemi Covid-19 telah dilakukan di berbagai negara, seperti Vietnam (La et al., 2020), Spanyol (Criado, Guevara-Gómez, \& Villodre, 2020), India (Das \& Dutta, 2020), Singapura (Wong \& Jensen, 2020), hingga Kanada (Bridgman et al., 2020; Teichmann et al., 2020b) dan Amerika Serikat (Papakyriakopoulos, Serrano, \& Hegelich, 2020). Perbandingan pemanfaatan media sosial pemerintah pada konteks Covid-19 antar negara juga telah dilakukan oleh Raamkumar, Tan, \& Wee (2020) untuk melihat kondisi perbandungannya. Penelitian ini hadir guna merangkum capaian dan permasalahan dari penelitian-penelitian terdahulu dari berbagai negara tersebut sehingga diperoleh konteks holistik media sosial pemerintah dan infodemi Covid-19 yang dapat digunakan sebagai masukan untuk menetapkan kebijakan pemanfaatan media sosial pemerintah di Indonesia. 
Konteks yang menyeluruh perihal media sosial pemerintah dan infodemi Covid-19 memerlukan perspektif yang relevan. Mergel (2013) mengedepankan pentingnya partisipasi, kolaborasi, dan transparansi. Lee \& Kwak (2012) dalam upaya untuk mendalami tentang engagement berbasis media sosial menggunakan perspektif Open Government Maturity Model (OGMM) yang terdiri dari kondisi awal, transparansi data, partisipasi terbuka, kolaborasi terbuka, yang dipungkasi dengan keterlibatan yang masif. Kedua perspektif tersebut memiliki sejumlah kesamaan yang juga dirangkum oleh penelitian tentang komunikasi sektor publik pada era COVID-19 yang mengedepankan 3 pilar Open Government yaitu transparansi, partisipasi, dan kolaborasi (Lovari et al., 2020).

Mergel (2013) yang mendalami konsep Government 2.0 mendefinisikan transparansi, partisipasi, dan kolaborasi dengan atribut 2.0. Transparansi 2.0 dikaitkan dengan penggunaan teknologi jejaring sosial untuk meningkatkan akuntabilitas pemerintahan. Melalui media sosial, pemerintah didorong untuk semakin transparan, termasuk dengan mempublikasikan informasiinformasi yang mungkin tidak diinginkan untuk diketahui masyarakat pada masa lalu. Bagaimanapun, pemerintah adalah pemilik begitu banyak data yang bisa jadi relevan pada sebagian atau seluruh masyarakat.

Penggunaan internet dan teknologi media sosial untuk menghubungkan masyarakat dengan pemerintah disebut sebagai partisipasi 2.0. Interaksi daring antara pemerintah dan masyarakat sesungguhnya telah muncul pada tahap Web 1.0 yang cenderung statis dan tidak interaktif. Web 2.0 yang kemudian berkembang menjadi Government 2.0 memungkinkan adanya interaksi dua arah pemerintah dan masyarakat, seperti pada kolom komentar laman Facebook, penggunaan Direct Message (DM) di Twitter, dan metode lainnya (Mergel, 2013).

Kolaborasi oleh Mergel (2013) dan Khan (2017) dikaitkan sebagai disrupsi media sosial pada hierarki, Standard Operating Procedure (SOP), maupun hukum yang berlaku di sektor publik. Faktanya, hierarki terbukti tidak efisien dalam koridor pencarian informasi mengingat adanya pembatasan informasi vertikal. Media sosial menunjukkan efek transformatif untuk berbagi pengetahuan dalam bidang administrasi publik. Dengan demikian penelitian ini bertujuan untuk memperoleh konteks yang menyeluruh mengenai media sosial pemerintah dan infodemi Covid19 dalam perspektif Open Government yang meliputi transparansi, partisipasi, dan kolaborasi.

Sesuai dengan tujuan untuk memperoleh konteks holistik tersebut, maka penelitian ini menggunakan pendekatan kualitatif. Menurut Creswell (2014) upaya memperoleh gambaran utuh dari suatu permasalahan melibatkan beragam perspektif serta menggunakan model yang sesuai untuk menjelaskan fenomena yang diteliti. Data-data yang digunakan dalam penelitian ini merupakan data publik yang meliputi hasil riset terdahulu yang telah dipublikasikan melalui jurnal ditunjang dengan data-data lain yang relevan. Interpretasi sebagai elemen dari pembahasan dan penarikan kesimpulan menggunakan tiga dimensi Open Government. 


\section{Transparansi: Meredam Rumor dan Stigma Dengan Medium yang Tepat}

Salah satu catatan dari Sohrabi et al. (2020) perihal penanganan COVID-19 pada periode awal wabah adalah transparansi. Negara-negara di dunia seolah-olah tidak belajar dari peristiwa wabah sebelumnya seperti SARS dan Zika. Minimnya transparansi memberikan ruang untuk diisi oleh rumor, stigma, hingga teori konspirasi, yang berpotensi menurunkan kepercayaan masyarakat baik pada pemerintah maupun pada lembaga internasional (Islam et al., 2020). Pada sejumlah negara, seperti di Indonesia, misinformasi publik kemudian juga diikuti oleh kurangnya komunikasi antar tingkatan pemerintahan sehingga memicu beredarnya interpetasi keliru melalui media sosial seperti WhatsApp, Facebook, dll (Djalante et al., 2020).

Menyikapi perkembangan pandemi, setiap negara memiliki kebijakannya masing-masing. Secara umum, pandemi Covid-19 menunjukkan bahwa krisis dapat mendorong keterbukaan atau malah mengaktivasi ketertutupan baik pada level pemerintahan lokal, nasional, hingga internasional (Lovari et al., 2020).

Secara umum, keterbukaan menjadi salah satu kunci sukses menangani pandemi. Dengan data kasus yang jelas, maka penelusuran kontak dapat dilakukan sehingga pendekatan kesehatan masyarakat berupa isolasi, karantina, hingga pembatasan komunitas dapat dilakukan dengan terarah. Sejumlah negara seperti Vietnam, Taiwan, hingga Singapura yang dinilai berhasil mengendalikan jumlah kasus Covid-19 mengimplementasikan pendekatan ini. Akan tetapi, sejumlah negara memilih untuk mengaktivasi ketertutupan, seperti misalnya Tanzania (Concerns, 2020). Pada perkembangannya, sejalan dengan pola komunikasi dan kebijakan pemimpin negara, asumsi bahwa Covid-19 adalah virus yang tidak berbahaya sampai pada masyarakat.

Begitu banyak asumsi berkembang tentang SARS-CoV-2 karena pada mulanya-sebagai penyakit yang baru-pengetahuan saintifik dan sosial perihal asal muasal hingga dampak dari virus ini masih minim. Hal itu memberi ruang pada hadirnya rumor hingga teori konspirasi yang terutama menyasar orang-orang yang mencari penjelasan (Papakyriakopoulos et al., 2020). Dalam perspektif lain, Alfirdaus \& Yuwono (2020) menyebut bahwa para pembuat kebijakan pun dihadapkan pada permasalahan yang belum jelas definisinya, namun sudah tampak dampak yang masif dan mengkhawatirkan.

Rumor dapat tersamar sebagai metode pencegahan infeksi maupun strategi pengendalian yang tampak kredibel namun justru berimplikasi serius. Islam et al. (2020) memaparkan sejumlah contoh. Di Iran, terdapat lebih dari 800 kematian, 60 kebutaan, serta 6.000 orang dirawat di rumah sakit karena konsumsi metanol. Hal itu terkait rumor yang beredar bahwa konsumsi alkohol berkonsentrasi tinggi dapat mendisinfeksi tubuh serta membunuh virus. Kasus serupa dengan rumor yang sama juga terjadi pada 30 kematian di Turki. Sedangkan di India, belasan orang mengalami keracunan tanaman pasca menyaksikan video di media sosial yang menyatakan bahwa Datura-yang notabene memang tanaman beracun-dapat memberikan imunitas pada Covid-19. Kejadian misinformasi juga muncul pada tingkat yang lebih tinggi yaitu organisasi. Pada 
sebuah gereja di Korea Selatan, penggunaan botol spray yang sama untuk menyemprotkan air garam kepada sesama jemaat menghasilkan lebih dari 100 kasus infeksi baru.

Penelitian Papakyriakopoulos et al. (2020) terhadap 4 media sosial yaitu Facebook, Twitter, Reddit, dan 4chan menampilkan fakta bahwa asal mula rumor hingga teori konspirasi adalah sumber alternatif, blog personal, maupun unggahan media sosial (83\%). Hanya ada $17 \%$ rumor maupun teori konspirasi yang berkembang dari media arus utama. Akan tetapi, dari proporsi yang kecil tersebut diperoleh jumlah share di Facebook dan Twitter 4 kali lipat lebih besar dibandingkan sumber alternatif. Pada saat yang sama, sumber arus utama memiliki jangkauan dan keberterimaan yang lebih luas di masyarakat.

Transparansi oleh pemerintah menjadi kunci penanganan Covid-19 yang baik. Bagaimanapun, pandemi telah memiliki dampak signifikan pada kepercayaan masyarakat. Sejumlah kecil maupun besar masyarakat yang tidak percaya pada pemerintah, media, praktisi kesehatan, maupun saintis akan mempengaruhi level kepercayaan dan kemampuan untuk membangun ulang hubungan di dalam komunitas. Lebih lanjut pada institusi publik, kegagalan untuk memperoleh kepercayaan dapat mendorong hilangnya kredibilitas, diperolehnya reputasi yang buruk, dan muaranya adalah ketidakpuasan publik. Pemerintah di banyak negara harus memahami bahwa penanganan pandemi Covid-19 telah mempercepat proses ketidakpercayaan publik pada sejumlah negara (Lovari et al., 2020).

Studi Wong \& Jensen (2020) di Singapura menyebut bahwa terdapat dua pilar komunikasi menuju transparansi yakni media konvensional dan media sosial. Pemerintah Singapura menggunakan WhatsApp sebagai elemen media sosial dan hal ini sangat relevan karena dari 5,7 juta penduduk, sebanyak 4 juta diantaranya adalah pengguna WhatsApp. Dengan demikian, pemerintah dapat mendiseminasikan informasi yang mutakhir dan terpercaya untuk mengisi ruang yang tadinya memungkinkan rumor berkembang. Bahkan pada saat kasus pertama muncul, pemerintah Singapura secara transparan mempublikasikan penelusuran kontak melalui WhatsApp, Twitter, Facebook, Telegram, maupun situsweb khusus. Pembaruan informasi juga dilakukan 2-3 kali sehari.

Transparansi melalui media sosial juga dilakukan oleh Vietnam. Sebelum kasus pertama terkonfirmasi, kebijakan pemerintah difokuskan pada penilaian terhadap ancaman yang mungkin terjadi, dilengkapi dengan pengembangan pedoman hingga perencanaan langkah-langkah preventif untuk menghadapi penyakit baru. Kewaspadaan di Vietnam sendiri sudah dimulai sejak peningkatan karantina perbatasan pada 3 Januari 2020. Hal itu kemudian ditunjang aktivitas di media sosial untuk mengkomunikasikan informasi perihal virus Corona kepada masyarakat (La et al., 2020).

Pada perkembangannya, Vietnam dan Singapura cukup berhasil menangani pandemi Covid-19 dengan jumlah kasus yang terkontrol dan angka kematian yang rendah. Hal ini menjadi kontradiksi dengan yang terjadi di Indonesia. Aliran informasi di Indonesia cukup lambat yang ditunjang pula oleh tertutupnya informasi perihal suspek sehingga membentuk kurangnya 
urgensi kegawatdaruratan pada masyarakat (Djalante et al., 2020). Padahal, persepsi bahaya yang rendah pada fase awal wabah bukan merupakan kondisi yang ideal. Salah satu buktinya adalah ketika sekolah tatap muka ditutup secara nasional pada pertengahan Maret 2020, sejumlah orang justru memanfaatkannya untuk bepergian. Selain itu, Indonesia juga mengalami kendala dalam penggunaan terminologi seperti outbreak hingga social distancing.

Alfirdaus \& Yuwono (2020) menekankan bahwa kebijakan business as usual maupun kebijakan pada situasi krisis tidaklah cukup untuk menjelaskan tentang pandemi Covid-19. Terlebih, krisis ini telah melintasi batas daerah maupun negara tertentu dan telah menjadi isu global yang disebabkan oleh penyebab non-struktural yang sulit dikendalikan dengan penuh ketidakpastian pada berbagai aspek. Salah satu masalah yang relevan dengan hal tersebut adalah fakta di Irak bahwa kepanikan tidak hanya muncul karena misinformasi, tetapi juga karena dirilisnya informasi faktual berupa laporan jumlah kasus dan jumlah kematian (Ahmad \& Murad, 2020). Di Indonesia, misalnya, pada hari pengumuman kasus pertama Covid-19 pada 2 Maret 2020 sempat terjadi kepadatan di pasar dan pusat perbelanjaan karena sebagian publik yang panik melakukan aksi borong kebutuhan pokok. Artinya, informasi yang harus dikelola tidak sekadar misinformasi, tetapi juga informasi yang benar-benar ada.

Walau demikian, perhatian khusus untuk transparansi pemerintah di media sosial demi menjegal beredarnya rumor dan teori konspirasi hendaknya tetap menjadi yang utama. Rumor, stigma, hingga teori konspirasi yang bersisian dengan kegawatdaruratan kesehatan masyarakat sendiri bukanlah hal baru dan sudah ada bahkan sejak periode Human Immunodeficiency Sydrome (HIV) di Afrika. Menurut Islam et al. (2020) saat itu HIV dirumorkan sama persis dengan Covid-19 pada masa kini, bahwa penyakit tersebut tidaklah ada dan pengobatan yang diberikan justru beracun untuk manusia. Hal itu kemudian menciptakan penolakan pada terapi antiretroviral (ARV) di Afrika Selatan. Kejadian sejenis juga terjadi pada wabah Zika (2015-2016). Pada kasus Ebola, misinformasi yang beredar juga tidak jauh berbeda, bahkan menyebut bahwa pekerja kesehatanlah yang menyebarkan virus tersebut. Kondisi-kondisi tersebut memberi pengaruh pada kemampuan pekerja kesehatan untuk melakukan pengendalian.

Belajar dari pengalaman HIV, Ebola, hingga Zika, misinformasi yang didorong oleh rumor, stigma, hingga teori konspirasi dapat menciptakan implikasi serius pada kesehatan masyarakat, terutama jika bertentangan dengan pedoman yang berbasis sains. Islam et al. (2020) merekomendasikan bahwa dalam mengelola informasi, pemerintah hendaknya memahami pola dari rumor, stigma, maupun teori konspirasi yang terkait dengan Covid-19 sehingga mampu mengembangkan pesan komunikasi risiko yang tepat. Sejalan dengan yang sudah berjalan saat ini baik di Facebook, Twitter, maupun Instagram, suatu pemerintahan maupun lembaga internasional seperti World Health Organization (WHO) hendaknya tidak sekadar mengidentifikasi setiap rumor maupun teori konspirasi untuk kemudian mengklarifikasinya, tetapi juga melibatkan platform media sosial terkait untuk membantu menyebarkan informasi yang tepat. 
Rumor, stigma, hingga teori konspirasi sejatinya mengikuti tiga cara pikir yakni: (1) narasi utamanya adalah keberadaan konspirasi yang terkait individu maupun kelompok berkuasa dengan kepentingan spesifik; (2) validitasnya didasarkan pada bukti tidak langsung atau justru pada ketiadaan bukti; dan (3) disusun sedemikian rupa sehingga sulit dibantah, seperti misalnya dengan oversimplifikasi dengan menyebut 'menurut sebuah penelitian' atau 'seperti disebut pada sebuah buku'. Perlu diwaspadai bahwa konten semacam ini cenderung jauh lebih viral dibandingkan konten yang melakukan debunk atau klarifikasi terhadapnya (Papakyriakopoulos et al., 2020). Misinformasi cenderung terjadi pada orang-orang dengan keingintahuan yang melakukan pencarian secara daring perihal cara mengatasi SARS-CoV-2 dan pencarian tersebut berpotensi keliru (Apuke \& Omar, 2021).

Transparansi perlu dikelola dengan optimal sehingga selain menihilkan rumor dan teori konspirasi, juga mampu mencegah stigma. Islam et al. (2020) menyebut bahwa stigma maupun ketakutan akan diskriminasi dapat berkontribusi pada penularan, terutama tenaga kesehatan. Akibat adanya stigma, orang dengan gejala Covid-19 akan menyembunyikan gejala dan riwayat paparan mereka saat memeriksaan diri ke fasilitas kesehatan, sehingga petugas yang melakukan penanganan dengan Alat Pelindung Diri (APD) minimal menjadi mudah tertular sebagaimana yang terjadi Bangladesh. Ketakutan akan stigma juga memicu orang-orang untuk menghindar dari tes, padahal hal tersebut menjadi elemen penting untuk mengidentifikasi penyebaran suatu wabah. Perlu diperhatikan pula kepercayaan pada rumor, teori konspirasi maupun pengenaan stigma tidak memiki korelasi langsung dengan faktor-faktor seperti level pendidikan. Sebagai contoh, pasien 17 di Vietnam adalah orang berpendidikan tinggi dari kelas menengah ke atas yang menolak karantina mandiri selama 14 hari dan justru kemudian menjadi bagian dari penyebaran virus (La et al., 2020).

Dengan konteks pengguna media sosial yang luas, pemerintah juga perlu memetakan masyarakat penerima informasi. Sebagaimana Singapura mengoptimalkan WhatsApp karena persentase penggunanya besar, maka di Irak posisinya berbeda karena terdapat kecenderungan bahwa pria lebih cenderung menggunakan Facebook dan Twitter, sementara wanita menggunakan Instagram (Ahmad \& Murad, 2020). Konteksnya juga kemudian berlainan dengan Vietnam, yang selain menggunakan Facebook karena dipakai 57,34\% populasi, juga menggunakan media sosial bernama Zalo yang memiliki sekitar 100 juta pengguna (La et al., 2020).

Dimensi transparansi berkaitan dengan pendayagunaan media sosial pemerintah secara optimal, baik dalam pembuatan dan penayangan konten kepada publik serta pemilihan medium yang tepat untuk keberterimaan yang tinggi sebagaimana penggunaan WhatsApp di Singapura dan media sosial lokal di Vietnam. Elemen lain yang penting untuk mendukung transparansi adalah kecepatan dan ketepatan dalam penyampaian informasi kepada publik. Kombinasi tersebut dapat meminimalkan berkembangnya rumor dan teori konspirasi yang berpotensi mempengaruhi sikap serta perilaku masyarakat dalam penanganan pandemi. 


\section{Partisipasi: Urgensi Pengukuran Sentimen Publik}

Salah satu hal yang mendorong berkembangnya rumor, stigma, dan teori konspirasi di media sosial adalah dimungkinkannya seseorang berbagi pesan kepada orang lain terlepas dari benar atau tidaknya suatu informasi. Menurut Apuke \& Omar (2021), di Nigeria altruisme menjadi prediktor paling kuat perihal berbagi misinformasi terkait Covid-19 karena mendasari tindakan dengan maksud membantu orang lain dengan cara berbagi informasi. Media sosial kemudian mempermudah kreasi dan diseminasi informasi tersebut. Goel \& Gupta (2020) menyebut bahwa kekuatan terbesar dari platform media sosial adalah juga kelemahan utamanya. Informasi begitu mudah diakses dan tersedia dengan segera sedangkan kualitasnya belum tentu sejalan.

Seperti telah dipaparkan pada bagian sebelumnya bahwa informasi yang dikonstruksi dari sekadar hipotesis belaka dapat dengan mudah dipaparkan pada audiens yang naif sehingga menciptakan rumor, stigma, hingga teori konspirasi di masyarakat. Pada saat yang sama, meneruskan atau membagikan suatu berita merupakan elemen dari citizens engagement (Bonsón et al., 2017). Pennycook et al. (2020) menekankan bahwa pada dasarnya setiap orang memiliki tendensi untuk tertahan terlebih dahulu apabila saat ingn menyebarkan suatu berita muncul pertanyaan tentang akurasi.

Partisipasi menjadi elemen penting dari citizens engagement karena melalui partisipasi publik dengan memberi like, menulis komentar, hingga membagikan suatu konten, pemerintah dapat menilai respon publik pada informasi yang dibuat sebagai produk dari transparansi. Hal ini yang kemudian menjadi kritik bahkan jauh sebelum pandemi.

Medaglia \& Zheng (2017) yang melakukan kajian literatur sistematik pada sejumlah penelitian tentang media sosial pemerintah mendapati bahwa riset-riset yang ada pada umumnya hanya berfokus pada pemerintah, bukan masyarakat sebagai pengguna. Selain itu, konten yang disediakan cenderung menjadi ajang promosi diri alih-alih mendorong transparansi, partisipasi, maupun pemberian layanan publik. Lebih dalam lagi, riset-riset tersebut pada umumnya berfokus dan berhenti pada aspek-aspek kuantitatif seperti jumlah like atau jumlah komentar. Kalaupun ada riset yang berfokus pada pengguna, permasalahannya juga sama yakni berhenti pada aspek kuantitatif.

Pada sejumlah penelitian terkini tentang media sosial dan Covid-19, mulai terjadi pengembangan. Penelitian Raamkumar et al., (2020) membandingkan konten pada laman Facebook Ministry of Health (MOH) Singapura, the Centers for Disease Control and Prevention (CDC) di Amerika Serikat, serta Public Health England (PHE) di Inggris baik sebelum dan sesudah COVID-19. Penelitian ini melakukan analisis sampai pada sentimen yang muncul dari masyarakat pada setiap konten sehingga tidak berhenti pada sekadar angka-angka engagement. Pengukuran sampai pada level sentimen juga dilakukan oleh Chen et al. (2020) untuk media sosial Weibo di Tiongkok. 
Menyoal sentimen, maka penelitian di Indonesia dari Gustomy (2020) memperlihatkan fakta menarik karena wacana kebijakan Covid-19 justru menjadi perang sentimen antara dua kutub klaster populis yang didominasi buzzer dan sebagian kecil influencer. Gawatnya adalah gaung dari buzzer dengan sentimen negatif cenderung menutupi suara kelompok kritis dan rasional. Penelitian ini juga memotret perdebatan yang tidak masuk akal secara substansi yaitu antara Presiden Joko Widodo dan Gubernur DKI Jakarta Anies Baswedan. Kondisinya adalah kedua tokoh tersebut sama-sama berada pada posisi pemerintah, meskipun berbeda level. Pertentangan itu kemudian menciptakan kegeraman rasional dari kelompok kritis yang sayangnya tidak menjadi trending topics. Hadirnya buzzer sendiri kemudian menciptakan engagement yang tidak organik dan menyebabkan wacana positif menjadi wacana pinggiran. Dari penelitian ini dapat dipahami urgensi untuk mendalami engagement lebih dari sekadar trending topics maupun jumlah like sebab ternyata partisipasi masyarakat berkelindan dengan para buzzer yang memiliki kepentingan masing-masing.

Shoaei \& Dastani (2020) menekankan bahwa media sosial dengan jejaringnya memiliki potensi besar untuk mendorong peningkatan kesadaran maupun edukasi terkait Covid-19. Pada periode awal pandemi, misalnya, media sosial mampu membantu mengendalikan pembatasan sosial serta mendorong orang-orang untuk menghindari aktivitas di luar rumah yang tidak terlalu penting. Hal itu juga didorong oleh adanya kolaborasi seperti yang terjadi Spanyol dan India (Criado et al., 2020; Das \& Dutta, 2020).

Guna memaksimalkan impresi publik beserta engagement-nya, diperlukan dua fitur utama media sosial pemerintah. Fitur pertama ialah konten. Sedangkan fitur kedua adalah hal-hal yang spesifik suatu akun seperti jumlah pengikut, posisi, konteks institusi, serta frekuensi aktivitas (Bridgman et al., 2020). Sejumlah penelitian telah memaparkan perihal atribut yang melekat pada fitur-fitur ini.

Pada media sosial TikTok, sebagaimana diteliti oleh Q Chen, Min, Zhang, Ma, \& Evans (2021) muncul gambaran partisipasi bahwa video yang lebih pendek cenderung mendapat lebih banyak engagement-berupa like dan komentar. Pada media sosial asli Tiongkok ini, berita tentang krisis COVID-19 sendiri cenderung menerima sedikit like apabila dibandingkan dengan konten seperti apresiasi untuk tenaga medis, penanganan oleh pemerintah, maupun panduan pada masa pandemi. Di TikTok, judul-judul positif cenderung mengundang engagement dari publik.

Sedangkan pada media sosial Weibo, riset Qiang Chen et al. (2020) memberikan perspektif lain bahwa kekayaan media tidak berasosiasi dengan citizens engagement dalam artian teks polos boleh jadi dapat memicu engagement lebih tinggi ketimbang gambar. Menariknya adalah fakta ini tidak disepakati oleh penelitian dari Yang, Deng, Zhang, \& Mao (2021) yang spesifik meneliti aktivitas media sosial pemerintah daerah di Wuhan, episenter pertama Covid-19. Pada penelitian tersebut, kekayaan media memiliki asosiasi dengan citizens engagement. Qiang Chen et al. (2020) sendiri menggunakan contoh akun Twitter Donald Trump yang memang nyaris tidak 
pernah membuat post berupa gambar dan hanya teks polos. Akan tetapi, pada konteks ini perlu dilihat lagi posisi Trump sebagai kepala negara adidaya sehingga engagement yang terjadi tidak serta merta bermakna dukungan untuk setiap tweet yang dibuat.

Partisipasi publik yang ditandai dengan citizens engagement, oleh Q Chen et al. (2021) disebut mengalami peningkatan saat terjadi dialog di media sosial, baik berupa penggunaan tagar tertentu, respon publik untuk menjawab pertanyaan atau justru membuat pertanyaan, serta mengajak atau mentions akun lain untuk terlibat dalam dialog. Dialog inilah yang membentuk hubungan antara publik dengan institusi sehingga mendorong citizens engagement. Interaksi yang muncul dari pemerintah akan memperlihatkan adanya perhatian pada pendapat publik, sehingga publik kemudian merasa lebih diakui dan diperhatikan sehingga terbentuk motivasi untuk melanjutkan engagement.

Guna mendorong partisipasi, Teichmann et al. (2020) menekankan sejumlah hal. Pertama, pada kondisi tertentu terkadang sosok yang membuat suatu post lebih penting daripada post itu sendiri. Dalam artian, ketika suatu konten edukasi pendekatan masyarakat terkait Covid-19 dibuat oleh para pemimpin nasional maupun daerah yang beraudiens luas, maka dampaknya akan lebih signifikan. Kedua, pesan ringkas yang diformulasikan secara jelas cenderung memperoleh engagement yang lebih masif. Muatan pesan yang kompleks seperti halnya pada penelitian pengembangan klorokuin dan hidroksiklorokuin hingga obat-obat yang sudah memiliki Emergency Use Authorization (EUA) seperti remdesivir dan favipiravir cenderung sulit memperoleh engagement yang sama dengan pesan-pesan terkait pendekatan kesehatan masyarakat seperti mencuci tangan, menggunakan masker, maupun menjaga jarak. Ketiga, kreativitas, media, dan kualitas media sangat penting. Informasi terkait Covid-19 harus dipasangkan dengan media yang relevan. Sebagai contoh, penjelasan tentang mekanisme vaksin akan lebih relevan jika dituangkan dalam bentuk video atau infografis alih-alih teks. Pada konteks lain, pemanfaatan jejaring influencer, referensi budaya pop, hingga penggunaan selebriti dapat menjadi strategi yang efektif sedangkan pesan yang terkait dengan kebijakan yang ekstensif maupun pesan berupa video dan infografis berkualitas rendah cenderung dapat menurunkan engagement. Keempat, pemerintah hendaknya menaruh perhatian perihal metode penyampaian informasi pada setiap platform. Pesan di Facebook dan Twitter mungkin dapat sama, tetapi metode penyampaiannya sangat berbeda, mulai dari ukuran foto, jumlah karakter pada caption, hingga penggunaan tagar. Untuk penggunaan di Kanada, video lebih memperoleh engagement di Twitter sementara pesan teks mendapatkannya di Facebook.

Untuk mendorong partisipasi publik, strategi media sosial perlu dirumuskan dengan komprehensif dan tidak dapat dilakukan serta merta dengan membuat post lalu diunggah di berbagai media sosial. Diperlukan pemahaman dan strategi konten yang tepat, disesuaikan pula dengan audiens pada masing-masing media sosial, untuk bisa menciptakan komunikasi publik melalui media sosial pemerintah yang mendapatkan partisipasi dan engagement dari publik. 
Menyoal pelibatan influencer, Vietnam memberikan contoh yang baik. Sejak awal pandemi, media sosial pemerintah didukung oleh upaya individual untuk mendukung kewaspadaan publik dan perlindungan terhadap virus. Sebagai contoh, lagu tentang mencuci tangan ('Ghen Co Vy') dari artis Quang Dang berhasil menjadi viral dan berulangkali direproduksi oleh warganet sehingga dampak edukasinya dapat diperoleh. Karantina-yang menjadi pembeda Vietnam dengan sejumlah negara lain di Asia Tenggara-juga dibantu berita positif dari seorang fashionista lokal bernama Chau Bui dengan videonya saat menjalani masa karantina yang menarik lebih dari 1 juta view (La et al., 2020).

Walau demikian, harus diwaspadai pula respon media sosial berupa hoaks terutama apabila melibatkan sosok terkenal. Di Vietnam, hal itu terjadi pada pasien ke-17 yang melibatkan selebriti dan orang terkenal. Untuk itu, Vietnam mengenakan hukuman denda pada penyebaran hoaks dengan nilai mencapai 3-6 kali upah mininum bulanan di negeri tersebut (La et al., 2020).

Shoaei \& Dastani (2020) menekankan bahwa penggunaan media sosial untuk penyebaran individu selama pandemi Covid-19 memungkinkan adanya perubahan perilaku individu dalam komunitas. Akan tetapi, ditekankan kembali potensi permasalahan karena informasi yang tidak tepat sebagai kombinasi dari kesempatan untuk membagikan informasi pada jejaring sosialnya dengan minimnya pemantauan saintifik atas informasi kesehatan yang terpublikasi pada jejaring tersebut. Adapun dampak pada orang per orang akan berbeda tergantung berbagai aspek seperti jenis kelamin, usia, hingga tingkat pendidikan yang pada implementasinya juga tidak dapat dipukul rata level pengaruhnya.

Menurut Sommariva, Vamos, Mantzarlis, Đào, \& Martinez Tyson (2018) kampanye melalui media sosial dapat berpotensi menjadi tidak efektif ketika terjadi kelimpahan pesan yang kemudian saling berkompetisi di media sosial sehingga mereduksi kemungkinan informasi kesehatan masyarakat untuk terlihat. Terlebih jika merujuk penelitian Sulistyawati et al. (2021), pengetahuan publik pada Covid-19 sebenarnya telah cukup baik. Hanya saja, sebagian orang yang punya sikap positif pada Covid-19 memiliki tendensi untuk merespon negatif pada kebijakan pemerintah.

Respon negatif pada kebijakan pemerintah seringkali dikaitkan dengan faktor preferensi politik. Penelitian Gustomy (2020) dapat digunakan untuk membantah pendapat tersebut karena media sosial kemudian menjadi gelanggang adu sentimen dalam polarisasi politik yang menutup suara orang-orang yang kritis dan rasional. Hal itu dilengkapi oleh Pennycook et al., (2020) yang menyatakan bahwa tidak ada relevansi partisan atau tidaknya seseorang dengan kepedulian maupun ketidakpedulian pada konteks misinformasi Covid-19. Pada riset yang sama, disebutkan bahwa lebih dari 1.700 responden memperlihatkan bahwa orang-orang membagikan informasi keliru tentang Covid-19 karena mereka gagal untuk berpikir mengenai keakuratan konten yang dibagikan. Poin pentingnya adalah terdapat kesamaan pola dengan yang terjadi pada hoaks politik. 
Media sosial telah dipahami sebagai sumber informasi favorit (Sulistyawati et al., 2021). Misinformasi pada media sosial dapat mendorong masyarakat untuk memilih metode penanganan yang efektif secara over reaktif atau-yang lebih berbahaya-menganggap pandemi tidak berbahaya sehingga abai pada protokol kesehatan yang lantas berpotensi memperluas penyebaran virus (Pennycook et al., 2020). Contoh krisis yang tercipta karena informasi adalah pada wabah Zika di Amerika Serikat (2015-2016). Sommariva et al. (2018) menyebut bahwa pada awalnya perhatian pada Zika cenderung rendah karena gejalanya cukup ringan dengan angka kematian rendah. Akan tetapi, perhatian kemudian meningkat setelah ditemukan bukti perihal malformasi janin pada akhir 2015. Perubahan suasana di media sosial dapat terjadi oleh karena pembaruan informasi.

Dalam prinsip partisipasi, publikasi ilmiah memainkan peranan penting untuk melawan mitos dan untuk mengkomunikasikan informasi yang memadai secara cepat kepada publik dan pada akhirnya mampu meredam rumor maupun teori konspirasi. Di Vietnam, publikasi ilmiah tersebut digunakan oleh media maupun media sosial untuk menyebarkan informasi kepada publik secara lebih luas. Hal itu didukung oleh oleh sejumlah pakar yang menggunakan akun media sosialnya sendiri untuk menginformasikan sesuatu kepada komunitas, contohnya adalah Tran Xuan Bach, Associate Professor dari John Hopkins University (La et al., 2020). Di Indonesia, sejumlah tenaga kesehatan juga menggunakan platform media sosialnya untuk menyederhanakan publikasi ilmiah, seperti misalnya Bimo A. Tejo, PhD. (@ba.tejo) pakar bioteknologi asal Indonesia di Universiti Putra Malaysia, dr. Adam Prabata (@adamprabata) kandidat PhD Medical Science di Kobe University, hingga dr. Tirta yang merupakan dokter sekaligus influencer. Hadirnya para tenaga kesehatan tersebut sejalan dengan hasil penelitian Teichmann et al. (2020) bahwa pendekatan spesifik lebih efektif untuk diterapkan terutama dalam menerjemahkan informasi saintifik dan teknis ke dalam terminologi yang sederhana.

Dalam mengantisipasi misinformasi di media sosial, pemerintah dapat melakukan intervensi awal. Cara pertama adalah dengan melakukan koreksi informasi dengan segera melalui debunk atau klarifikasi. Sayangnya, sejumlah fakta menyebut bahwa klarifikasi cenderung tidak seviral hoaks aslinya sehingga jangkauan koreksi informasi tidak seluas peredaran misinformasinya. Untuk itu diperlukan cara kedua yakni mengetahui lebih dini rumor yang berkembang langsung melalui platform media sosialnya untuk kemudian ditandai dan dikurangi kemungkinan untuk dilihat oleh lebih banyak orang dengan penyesuaian algoritma (Sommariva et al., 2018). Penyesuaian algoritma menjadi penting karena disebutkan oleh González-Padilla \& Tortolero-Blanco (2020) bahwa dengan konsep filter gelembung seperti yang ada sekarang, algoritma akan mengarahkan data yang hendak ditampilkan kepada preferensi seseorang. Dengan demikian, apabila preferensi seseorang adalah teori konspirasi, maka aktivitas di media sosial maupun data-data sejenis akan muncul pada pencarian di internet. 
Raamkumar et al. (2020) menawarkan kepada otoritas yang terkait dengan kesehatan masyarakat untuk mempertimbangkan alokasi sumber daya khusus untuk mengelola komentar toksik di media sosial, sebagaimana juga melakukan koreksi pada misinformasi yang beredar. Pada akun CDC di Amerika Serikat, komentar toksik cenderung lebih tinggi sejalan dengan pernyataan presiden kala itu, Donald J. Trump, bahwa SARS-CoV-2 adalah Chinese virus yang kemudian memicu sentimen anti-Asia. Komentar toksik patut menjadi perhatian karena penelitian dari Qiang Chen et al. (2020) menambahkan informasi bahwa valensi emosional yang termuat dalam partisipasi publik mampu memoderasi hubungan antara konten media sosial pemerintah dengan engagement yang diciptakan. Apabila pemerintah gagal mengelola valensi emosional dan kekayaan media pada konten yang dibuat, maka dapat memicu rendahnya engagement. Di sisi lain, apabila pemerintah mampu mengadopsi dialog timbal balik, maka dapat mendorong citizen engagement. Muaranya adalah citizens tersebut dapat memperoleh engagement dengan pendekatan kesehatan masyarakat yang menjadi kebijakan pemerintah sehingga dapat membantu mengakhiri pandemi Covid-19.

Qiang Chen et al. (2020) merekomendasikan pemerintah untuk memanfaatkan teknologi Artificial Intelligence (Al) dan cloud computing untuk menganalisis kebutuhan publik dan perubahan yang dibutuhkan pada setiap tahapan krisis. Media sosial pemerintah dapat memuaskan kebutuhan masyarakat melalui penyesuaian pada informasi krisis yang dibutuhkan oleh publik. Apabila kepuasan masyarakat terbentuk, maka akan mendorong pengaruh media sosial pemerintah di mata publik sehingga menjadikannya acuan informasi utama dengan mengabaikan misinformasi yang ada di media sosial secara umum.

Pengukuran sentimen di media sosial juga dapat membantu otoritas untuk mengukur efektivitas edukasi (Raamkumar et al., 2020). Dengan demikian, pemerintah dapat menentukan strategi untuk mengedukasi masyarakat dengan media sosial yang tepat (Shoaei \& Dastani, 2020). Hal ini juga dapat menjadi jawaban pada kritik Medaglia \& Zheng (2017) bahwa properti pada platform media sosial cenderung kurang diteliti sehingga berbeda dengan implementasi $e$ government pada awal perkembangannya karena begitu banyak pembahasan dilakukan pada situsweb sebagai platform utama. Pengukuran sentimen ini bersama-sama dengan pemetaan hoaks yang beredar serta pengetahuan yang relevan dapat menjadi alat bantu formulasi kebijakan yang efektif untuk mereduksi misinformasi (Apuke \& Omar, 2021). Pada saat yang sama, pemerintah juga didorong untuk melakukan dialog timbal balik guna mengoptimalkan citizens engagement melalui interaksi yang baik (Qiang Chen et al., 2020).

Pada akhirnya, optimalisasi pada citizens engagement, baik melalui pemanfaatan Al, moderasi komentar toksik, maupun pelibatan partisipasi influencer maupun tokoh-tokoh dari elemen tenaga kesehatan untuk turut mendorong edukasi dengan kualitas yang prima, harus didukung oleh penyediaan informasi yang valid, efektif, efisien, dan berkelanjutan kepada publik melalui kanal yang relevan untuk meningkatkan pemahaman tentang Covid-19. Lebih lanjut, 
pengalaman yang ada saat ini hendaknya dapat digunakan oleh pemerintah dan pemangku kepentingan lainnya untuk mempersiapkan penanganan pandemi lain di masa depan.

\section{Kolaborasi: Medium Interaksi Pemerintah-Masyarakat}

Apabila mengacu pada definisi kolaborasi 2.0 yang diperkenalkan oleh Mergel (2013), elemen tersebut belum dapat dipenuhi oleh pemerintah di berbagai negara sampai saat ini. Konsep kolaborasi 2.0 cenderung menyerupai Wikipedia ketika baik pemerintah maupun masyarakat berkolaborasi pada platform yang sama. Dalam konteks penanggulangan Covid-19, hal itu belum terjadi pada banyak negara. Di Spanyol terdapat gerakan yang melibatkan platform digital kolaboratif namun tidak secara langsung melibatkan pemerintah. Walau demikian gerakan yang diberi nama 'Frena la Curva' atau 'landaikan kurvanya' ini dibuat untuk mendukung pemerintah dan pelayanan publik. Sistematikanya adalah dengan penyediaan kebutuhan masyarakat, mulai dari masker hingga buku untuk pelajar sekolah dasar yang kebutuhannya ditampilkan pada suatu platform untuk kemudian dipenuhi oleh masyarakat lain yang berkelebihan (Criado et al., 2020).

Kolaborasi yang terjadi sejauh ini adalah lebih kepada gerakan partisipasi yang mengarah pada kolaborasi. Di India, misalnya, dalam penerapan jam malam, maka pemerintah membuat tagar \#JanataCurfew yang kemudian didukung oleh para selebriti dengan membuat konten afirmasi (Das \& Dutta, 2020). Di Spanyol, hal yang serupa dilakukan pula dengan tagar \#EsteVirusloParamosUnidos atau bersama-sama untuk menghentikan virus. Tagar tersebut didesain sebagai bagian dari kampanye institusi di media sosial untuk meningkatkan kesadaran akan krisis Covid-19 dan kemudian juga dibawa dalam periode lockdown di Spanyol. Kolaborasi pada tagar ini terjadi karena akun otoritas kesehatan masyarakat (@saludpublicaes), polisi nasional (@policia),dan Kementerian Kesehatan (@sanidadgob) mendapat banyak retweet dari masyarakat sehingga penyebaran informasi terbilang optimal.

Kolaborasi lain yang dilakukan terkait dengan Covid-19 pada masa pandemi adalah pelaksanaan riset maupun survei kolaboratif melalui media sosial, termasuk pula kegiatan edukasi berbasis tayangan live secara daring melalui Zoom, YouTube, maupun Instagram dan Facebook Live (González-Padilla \& Tortolero-Blanco, 2020). Berbagai wujud kolaborasi meskipun belum mengarah pada definisi ideal kolaborasi 2.0 perlu untuk dipertahankan guna menjaga konteks positif. Menurut Das \& Dutta (2020) secara umum sentimen positif terkait Covid-19 pada diskursus publik masih sedikit lebih tinggi dibandingkan sentimen negatif.

Pendekatan apapun yang tengah dilakukan, baik dari perspektif kesehatan, ekonomi, administrasi publik, maupun pemerintahan bermuara pada tujuan yang sama yakni kurva yang melandai. Untuk bisa mencapai tujuan tersebut diperlukan kolaborasi seluruh pihak (Lovari et al., 2020). 
Media sosial tetap merupakan instrumen yang ideal untuk melakukan edukasi dan komunikasi mengingat keunggulannya berupa penyebaran konten edukasi yang cepat. Walau demikian, penting bagi pemerintah untuk selalu memperhatikan informasi yang beredar di masyarakat karena selalu memiliki kemungkinan untuk tidak lagi mutakhir, belum peer-review, tidak valid, tidak benar, tidak relevan pada lingkungan tertentu, atau bahkan sama sekali keliru (González-Padilla \& Tortolero-Blanco, 2020). Sebagaimana yang disampaikan oleh Abdelsalam et al. (2013) dalam konteks Arab Spring, media sosial merupakan enabler yang relevan dan besarnya perubahan dari tahun ke tahun akan mendorong sedikit demi sedikit terwujudnya NPS antara lain melalui interaksi pada level akar rumput dengan masyarakat untuk mendorong perubahan dan reformasi ke arah yang lebih baik. Kolaborasi, bersama-sama dengan transparansi dan partisipasi, menjadi elemen penting dalam tata kelola terhadap infodemi Covid-19 di media sosial yang merupakan perang jangka panjang hingga berakhirnya masa pandemi.

\section{Penutup}

Konteks media sosial pemerintah dan infodemi Covid-19 dapat dilihat dengan perspektif Open Government yaitu transparansi, partisipasi, dan kolaborasi. Berdasarkan studi literatur yang dilakukan, dapat disimpulkan bahwa transparansi berkaitan dengan pemanfaatan media sosial pemerintah secara optimal, baik dalam pembuatan maupun penayangan konten kepada publik serta pemilihan medium yang tepat untuk keberterimaan yang tinggi. Hal itu juga didukung oleh kecepatan dan ketepatan dalam penyampaian informasi kepada publik sehingga mampu mereduksi perkembangan rumor dan teori konspirasi yang berpotensi mempengaruhi sikap dan perilaku masyarakat dalam penanganan pandemi. Dari sudut pandang partisipasi, relevansinya adalah pada pengukuran sentimen publik di media sosial sebab studi literatur justru menyebut peran partisipasi pada perkembangan infodemi melalui penyebaran lebih lanjut suatu misinformasi maupun interaksi berupa komentar toksik di media sosial pemerintah. Pada perspektif kolaborasi, belum terdapat interaksi aktif pemerintah dan publik pada satu platform sebagaimana definisi kolaborasi 2.0. Dengan demikian, ruang lingkup kolaborasi pada media sosial adalah medium interaksi level akar rumput guna mendorong perubahan ke arah yang lebih baik.

Penelitian ini merekomendasikan kepada pemerintah baik tingkat pusat maupun daerah untuk memberdayakan media sosialnya secara optimal dengan penayangan konten kepada publik secara cepat dan tepat yang ditunjang dengan pemilihan platform yang memiliki keberterimaan tinggi di masyarakat. Sesudah konten media sosial diterima oleh publik, pemerintah hendaknya secara terus-menerus mengoptimalisasi citizens engagement, baik melalui pemanfaatan Al, moderasi komentar toksik, hingga mendorong partisipasi ke arah kolaborasi antara berbagai pihak yang kompeten. Implementasi hal-hal tersebut diharapkan 
dapat mengoptimalkan strategi pemanfaatan media sosial guna memerangi infodemi sehingga pandemi Covid-19 dapat diatasi dengan baik.

\section{Ucapan Terima Kasih}

Terima kasih kepada para admin media sosial @vokabolari atas bantuan penyediaan sumbersumber pustaka yang mutakhir dan Yovita Diane Titiesari serta Kristofer Aditya Aryadharma untuk pendampingan dalam penulisan artikel ini.

\section{Pendanaan}

Penulisan artikel ini berada dalam pembiayaan beasiswa Lembaga Pengelola Dana Pendidikan (LPDP) Kementerian Keuangan Republik Indonesia.

\section{Daftar Pustaka}

Abdelsalam, H. M., Reddick, C. G., Gamal, S., \& Al-shaar, A. (2013). Social Media in Egyptian Government Websites: Presence, Usage, and Effectiveness. Government Information Quarterly, 30(4), 406-416.

Ahmad, A. R., \& Murad, H. R. (2020). The Impact of Social Media on Panic During the COVID-19 Pandemic in Iraqi Kurdistan: Online Questionnaire Study. J Med Internet Res, 22(5). https://doi.org/10.2196/19556

Alfirdaus, L. K., \& Yuwono, T. (2020). Pandemi Covid-19 dan Pendekatan Kebijakan Multikrisis: Sebuah Refleksi Teoritis. JIIP: Jurnal IImiah IImu Pemerintahan, 5(2), 206-216.

Apuke, O. D., \& Omar, B. (2021). Fake news and Covid-19: Modelling The Predictors of Fake News Sharing Among Social Media Users. Telematics and Informatics, 56, 101475.

Bonsón, E., \& Bednárová, M. (2018). The use of YouTube in Western European Municipalities. Government Information Quarterly, 35(2), 223-232.

Bonsón, E., Perea, D., \& Bednárová, M. (2019). Twitter As a Tool For Citizen Engagement: An Empirical Study of The Andalusian Municipalities. Government Information Quarterly, 36(3), 480-489.

Bonsón, E., Royo, S., \& Ratkai, M. (2017). Facebook Practices in Western European Municipalities: An Empirical Analysis of Activity and Citizens' Engagement. Administration \& Society, 49(3), 320-347.

Bridgman, A., Merkley, E., Loewen, P. J., Owen, T., Ruths, D., Teichmann, L., \& Zhilin, O. (2020). The causes and Consequences of Covid-19 Misperceptions: Understanding the Role of News and Social Media. Harvard Kennedy School Misinformation Review, 1(3).

Chen, Q., Min, C., Zhang, W., Ma, X., \& Evans, R. (2021). What Drives Citizen Engagement in Government TikTok During Public Health Emergencies: The Case of Covid-19. Journal of Medical Internet Research.

Chen, Q., Min, C., Zhang, W., Wang, G., Ma, X., \& Evans, R. (2020). Unpacking the Black Box: How 
to Promote Citizen Engagement Through Government Social Media During The Covid-19 Crisis. Computers in Human Behavior, 110, 106380.

Cinelli, M., Quattrociocchi, W., Galeazzi, A., Valensise, C. M., Brugnoli, E., Schmidt, A. L., ... Scala, A. (2020). The Covid-19 Social Media Infodemic. ArXiv Preprint ArXiv:2003.05004.

Concerns, T. - C. (2020). Tanzania - Coronavirus Concerns. Africa Research Bulletin: Political, Social and Cultural Series, 57(5), 22726. https://doi.org/10.1111/j.1467-825x.2020.09469.x

Creswell, J. (2014). Penelitian Kualitatif \& Desain Riset: Memilih di Antara Lima Pendekatan (A. Lazuardi, Trans.). Yogyakarta: Pustaka Pelajar.(Original Work Published 1998).

Criado, J. I., Guevara-Gómez, A., \& Villodre, J. (2020). Using Collaborative Technologies and Social Media to Engage Citizens and Governments During the Covid-19 Crisis The case of Spain. Digital Government: Research and Practice, 1(4), 1-7.

Criado, J. I., Sandoval-Almazan, R., \& Gil-Garcia, J. R. (2013). Government Innovation Through Social Media. Elsevier.

Das, S., \& Dutta, A. (2020). Characterizing Public Emotions and Sentiments in Covid-19 Environment: A Case Study of India. Journal of Human Behavior in the Social Environment, $1-14$.

Denhardt, J. V, \& Denhardt, R. B. (2015). The New Public Service Revisited. Public Administration Review, 75(5), 664-672.

Djalante, R., Lassa, J., Setiamarga, D., Sudjatma, A., Indrawan, M., Haryanto, B., ... Rafliana, I. (2020). Review and Analysis of Current Responses to Covid-19 in Indonesia: Period of January to March 2020. Progress in Disaster Science, 6, 100091.

Goel, A., \& Gupta, L. (2020). Social Media in the Times of Covid-19. Journal of Clinical Rheumatology.

González-Padilla, D. A., \& Tortolero-Blanco, L. (2020). Social Media Influence in the Covid-19 Pandemic. International Braz j Urol, 46, 120-124.

Gustomy, R. (2020). Pandemi ke Infodemi: Polarisasi Politik dalam Wacana Covid-19 Pengguna Twitter. JIIP: Jurnal IImiah IImu Pemerintahan, 5(2), 190-205.

Islam, M. S., Sarkar, T., Khan, S. H., Kamal, A.-H. M., Hasan, S. M. M., Kabir, A., ... Anwar, K. S. (2020). Covid-19 Related Infodemic and its Impact on Public Health: A Global Social Media Analysis. The American Journal of Tropical Medicine and Hygiene, 103(4), 1621.

Kemp, S. (2020). Digital 2020 Global Digital Overview. Retrieved from https://wearesocial.com/digital-2020

Khan, G. F. (2017). Social Media for Government. Social Media for Government, 7-21.

La, V.-P., Pham, T.-H., Ho, M.-T., Nguyen, M.-H., P Nguyen, K.-L., Vuong, T.-T., ... Vuong, Q.-H. (2020). Policy Response, Social Media and Science Journalism for the Sustainability of the Public Health System amid the Covid-19 Outbreak: The Vietnam Lessons. Sustainability, 12(7), 2931.

Lee, G., \& Kwak, Y. H. (2012). An Open Government Maturity Model for social media-based public 
engagement. Government Information Quarterly, 29(4).

Lovari, A., D’Ambrosi, L., \& Bowen, S. A. (2020). Re-Connecting Voices. The (New) Strategic Role of Public Sector Communication After the Covid-19 Crisis. Partecipazione e Conflitto, 13(2), 970-989.

Medaglia, R., \& Zheng, L. (2017). Mapping Government Social Media Research and Moving it Forward: A Framework and a Research Agenda. Government Information Quarterly, 34(3), 496-510.

Mergel, I. (2013). A Framework for Interpreting Social Media Interactions in the Public Sector. Government Information Quarterly, 30(4), 327-334.

Papakyriakopoulos, O., Serrano, J. C. M., \& Hegelich, S. (2020). The Spread of Covid-19 Conspiracy Theories on Social Media and the Effect of Content Moderation. The Harvard Kennedy School (HKS) Misinformation Review, 1.

Pennycook, G., McPhetres, J., Zhang, Y., Lu, J. G., \& Rand, D. G. (2020). Fighting Covid-19 Misinformation on Social Media: Experimental Evidence for A Scalable Accuracy-Nudge Intervention. Psychological Science, 31(7), 770-780.

Raamkumar, A. S., Tan, S. G., \& Wee, H. L. (2020). Measuring The Outreach Efforts of Public Health Authorities and The Public Response on Facebook During The Covid-19 Pandemic in Early 2020: Cross-Country Comparison. Journal of Medical Internet Research, 22(5), e19334.

Shoaei, M. D., \& Dastani, M. (2020). The Role of Social Media During The Covid-19 Crisis: a Narrative Review. Health Technology Assessment in Action, 4(1).

Sohrabi, C., Alsafi, Z., O’Neill, N., Khan, M., Kerwan, A., Al-Jabir, A., ... Agha, R. (2020). World Health Organization Declares Global Emergency: A Review of The 2019 Novel Coronavirus (Covid-19). International Journal of Surgery, 76, 71-76.

Sommariva, S., Vamos, C., Mantzarlis, A., Đào, L. U.-L., \& Martinez Tyson, D. (2018). Spreading The (fake) News: Exploring Health Messages on Social Media and the Implications For Health Professionals Using a Case Study. American Journal of Health Education, 49(4), 246-255.

Sulistyawati, S., Rokhmayanti, R., Aji, B., Wijayanti, S. P. M., Hastuti, S. K. W., Sukesi, T. W., \& Mulasari, S. A. (2021). Knowledge, Attitudes, Practices and Information Needs During the Covid-19 Pandemic in Indonesia. Risk Management and Healthcare Policy, 14, 163.

Teichmann, L., Nossek, S., Bridgman, A., Loewen, P., Owen, T., Ruths, D., \& Zhilin, O. (2020a). Public Health Communication and Engagement on Social Media during the COVID-19 Pandemic.

Teichmann, L., Nossek, S., Bridgman, A., Loewen, P., Owen, T., Ruths, D., \& Zhilin, O. (2020b). Public Health Communication and Engagement on Social Media During the COVID-19 Pandemic.

Wong, C. M. L., \& Jensen, O. (2020). The Paradox of Trust: Perceived Risk and Public Compliance During the Covid-19 Pandemic in Singapore. Journal of Risk Research, 23(7-8), 1021-1030.

Wu, Z., \& McGoogan, J. M. (2020). Characteristics of and Important Lessons From the Coronavirus 
Disease 2019 (COVID-19) Outbreak in China: Summary of a Report of 72314 Cases From the Chinese Center for Disease Control and Prevention. Jama. https://doi.org/doi:10.1001/jama.2020.2648

Yang, Y., Deng, W., Zhang, Y., \& Mao, Z. (2021). Promoting Public Engagement during the COVID19 Crisis: How Effective Is the Wuhan Local Government's Information Release? International Journal of Environmental Research and Public Health, 18(1), 118.

Zhang, S., Pian, W., Ma, F., Ni, Z., \& Liu, Y. (2021). Characterizing the Covid-19 Infodemic on Chinese Social Media: Exploratory Study. JMIR Public Health and Surveillance, 7(2), e26090.

\section{Tentang Penulis}

Alexander Arie Sanata Dharma merupakan Mahasiswa Program Magister Ilmu Administrasi Universitas Indonesia dengan peminatan administrasi dan kebijakan publik.

Azhar Kasim adalah Dosen Fakultas Ilmu Administrasi Universitas Indonesia dengan bidang riset administrasi publik, kebijakan publik, evaluasi program, perilaku organisasi, hingga good governance. 